\title{
Author Correction: High-performance compliant thermoelectric generators with magnetically self- assembled soft heat conductors for self-powered wearable electronics
}

Byeongmoon Lee (1), Hyeon Cho, Kyung Tae Park, Jin-Sang Kim, Min Park, Heesuk Kim (1), Yongtaek Hong (D) \& Seungjun Chung (1)

Correction to: Nature Communications https://doi.org/10.1038/s41467-020-19756-z, published online 23 November 2020.

Affiliation 1 incorrectly read 'Department of Electronic and Computer Engineering, Inter-University Semiconductor Research Center (ISRC), Seoul National University, Seoul, 08826, Korea' instead of the correct 'Department of Electrical and Computer Engineering, Inter-University Semiconductor Research Center (ISRC), Seoul National University, Seoul, 08826, Korea’.

Published online: 19 February 2021

(c) (i) Open Access This article is licensed under a Creative Commons Attribution 4.0 International License, which permits use, sharing, adaptation, distribution and reproduction in any medium or format, as long as you give appropriate credit to the original author(s) and the source, provide a link to the Creative Commons license, and indicate if changes were made. The images or other third party material in this article are included in the article's Creative Commons license, unless indicated otherwise in a credit line to the material. If material is not included in the article's Creative Commons license and your intended use is not permitted by statutory regulation or exceeds the permitted use, you will need to obtain permission directly from the copyright holder. To view a copy of this license, visit http://creativecommons.org/licenses/by/4.0/.

(c) The Author(s) 2021 